\title{
Effects of seed priming on morphological and phonological characteristics of the coriander (Coriandrumsativum L.)
}

\begin{abstract}
In order to evaluate the effects of priming on the performance of the Coriander, an experiment under field conditions, was conducted randomized block design with 4 replications and 10 levels of treatments in 2016 in Agriculture and Natural Resources Research and Education Center of West Azerbaijan. The purpose of this research was to improve and modify the uniformity in germination, growth rate and subsequently high performance and production of qualified product. In this research Coriander seeds, in this research Coriander seeds, in compare with control group, were pretreated with water, Folic acid, humic acid, Ascorbic acid, $\mathrm{P}_{2} \mathrm{~K}_{2} \mathrm{SO}_{4}$, Zinc, $\mathrm{GA}_{3}$. Analysis of variance showed that the effect of priming on the agronomic performance measurements including fresh weight of plant, plant height, distance of the first branch from ground, number of umbels, number of compound leaves, leaf surface area, total dry weight and seed weight were significant. The variance analysis of field tests all traits studied had meaningful statistical difference in probability level of $1 \%$.
\end{abstract}

Volume 7 Issue 6 - 2017

\author{
Zarrin Jamshidian,' Farshid Talat ${ }^{2}$ \\ 'Graduate Student of Horticultural Biotechnology, Saba College \\ of Higher Education, Iran \\ ${ }^{2}$ Seed and plant improvement Research Department, West \\ Azarbaijan Agricultural and Natural Resources Research and \\ Education Center, Iran
}

\begin{abstract}
Correspondence: Farshid Talat, Assistant Professor, Seed and plant improvement Research Department, West Azarbaijan Agricultural and Natural Resources Research and Education Center, AREEO, Urmia, Iran, Email farshid.talat@gmail.com
\end{abstract}

Received: April 07, 2017| Published: October 27, 2017

Keywords: coriandrum sativum L; hormonal priming, hydro- priming, osmo priming, pre- treatment, performance

Abbreviations: $\mathrm{P}$, phosphorus; $\mathrm{K}_{2} \mathrm{SO}_{4}$, potassium sulfate; $\mathrm{GA}_{3}$, gibberellin; IAA, indole-3-acetic acid

\section{Introduction}

Nowadays the irregular increase of population in the world is a complex issue and is a crisis for the future. The evidences and statements show a large increase in accessible and useful plants that have medicinal properties. Due to side effects of chemical drugs, the use of traditional medicine, especially herbal therapy, is considered in recent decades. The use of medicinal plants has begun in the time when human started to know diseases and began to treat them. With the development of science and economic issues at the same time, the use of medicinal plants was reduced as it was in the past, and synthetic drugs used instead of them in many cases. As the new experiences shows the adverse effects of synthetic drugs, herbal medicine usage, in treating diseases, has been increased.

Since germination and seedling establishment are critical steps in plant life, and the successful establishment of plant, not only depend on rapid and uniform germination of seed but depend on the ability of rapid germination of the seed under environmental conditions. For this purpose, seed pre-priming or priming methods was used to increase the qualitative and quantitative performances of medicinal plants. Seed priming is a technique which involves water uptake by seeds followed by drying to initiate the early events of germination up to the point of radicle emergence. Its benefits include rapid, uniform and increased germination, improved seedling vigor and growth under a broad range of environments resulting in better stand establishment and alleviation of phytochrome -induced dormancy in same crops. The techniques, which are commercially used to accomplish seed priming, have been reviewed in detail by Khan, Basu, MacDonald, Copeland and Mc Donald, and Varier and Vari.
The common feature in these priming techniques is that they all involve controlled uptake of water. The metabolic processes associated with priming are slightly different, with respect to their dynamics from those which occur during germination, where the water uptake is not controlled. Also, the salts used during priming elicit specific sub cellular responses Varier et al. Seed germination and seedling establishment, provides plant's survival and so is the most sensitive and critical phases in the growth cycle of plant species. Weak and uneven germination will lead to enormous financial losses in producing complexes, which reduces favorable conditions for mechanization and also the low price of plant's packages Subedi et al. ${ }^{1}$ Priming is one of the best methods which improve seed performance.

In priming, seeds are allowed to absorb some water, which causes seeds to pass early stages of germination, without growing root, in other words, seeds absorb water but will not enter the third stage of growth cycle and after priming, seeds dried out and like an untreated seeds (control) were stored and planted. Priming is a simple and safe economic technique, to increase the ability of the seeds in osmotic adjustment and increase seedling establishment and crop production, under the stressful conditions. This technique can cause more rapid appearance of roots and stems, production of plants with stronger stamina, higher tolerance to drought, earlier flowering, early harvesting, and to obtain crop in bad conditions Kaur et al. ${ }^{2}$ There are several different methods for seed priming including the osmo priming, hydro-priming, hormonal-priming and bio-priming and matric priming Esivand et al. ${ }^{3}$ The effect of priming on DNA repair, gene expression and synthesis of new message and protein synthesizing machinery are included. Coriander scientific name is Coriandrum sativum L. yearling herbaceous, without fluff and height of 30 to $60 \mathrm{~cm}$ and has an upright, transparent, and is more or less grooved stem Gahraman. ${ }^{4}$ 
It has tiny, umbelliferous and compound white or pink flowers Its leaves has two distinct types, one at the base and divided into pieces with shallow lobes and serrated and the other type is along with stem and has fiber like lamina Ullajadi. ${ }^{5}$ Fruit plants appear oval with dimensions of $2.5 \times 2.6 \mathrm{~mm}$, and its color is yellowish green to yellowish-brown due to drying comes in. $100 \mathrm{gr}$ Coriander seeds contain $7.5 \mathrm{gr}$ water, $15 \mathrm{gr}$ fatty acids (including oleic acid, linoleic acid, Petrosilinic acid, meristic acid, palmitic acid, Arachidic acid, stearic acid, linolenic acid), 1 gr Oxalic acid, 38gr Cellulose, 170mgr Calcium, 1 gr Essential oil, Vitamins (A, B , B , B , C), Vitamin A (200) unit and vitamin C (50) $\mathrm{mg}$. In addition, mannitol and flavonoid glycosides are present in fruits.

Flavonoid glycosides found in Coriander seeds are mucilage and phenolic acid and caffeic acid. Coriander essential oils contain $70-90 \%$ d-linalool or coriandrol, $20 \%$ mono terpenic hydrocarbons including $\alpha$ and $\gamma$ terpenes, $\alpha$ and $\beta$ flandron, p symene, (-) borneol and kaempferol and also the small amounts of aldehydsilic and ethers of linalitic Blumenthal et al. ${ }^{6}$ In traditional medicine, coriander is known as a plant with effects of food digesting, carminative, antinausea, anti-seizure, anti-epileptic, Anti-inflammatory and pain killer. Pharmacologic researches determined the effects of this herb such as reducing sugar and cholesterol levels in blood, anti-bacterial and anti-fungal effects. ${ }^{7,8}$ This study is accomplished with the aim of investigating the effects of different pre-treatments on morphological and phonological characteristics of the Coriander.

\section{Materials and methods}

The purpose of this study was to evaluate the effect of three types of seeds priming on the Coriandrer. This evaluation were conducted in a randomized complete block design with four replications and ten types of treatments including control group (without treatment), distilled water (hydro priming), indole-3- acetic acid (IAA) 20ppm and $\mathrm{GA}_{3} 40 \mathrm{ppm}$ (hormonal priming), Sulphate Potash $\left(\mathrm{K}_{2} \mathrm{SO}_{4}\right) 100 \mathrm{mmol}$, Zinc $100 \mathrm{mmol}$, Phosphorus $100 \mathrm{mmol}$, ascorbic acid $30 \mathrm{mg} / 1$, humic acid 200mg/1, folic acid $75 \mathrm{mmol}$ (osmo-priming).

To apply priming, seeds were soaked for 24 hours at $25^{\circ} \mathrm{C}$ (room temperature) in priming solution, after this period of time, the seeds were removed from distilled priming solution and then washed with water for 60 seconds and rinsed with distilled water to cleaned up the direct effects of the mentioned materials on the seeds to prevent shell damage .Then the Seeds dried at room temperature in a week. Pre-treated Seeds and Control seeds were planted in Agriculture and Natural Resources Research and Education Center of West Azerbaijan province in the field conditions. Treated seeds were planted in the rows with length of 10 meters and each row had $50 \mathrm{~cm}$ distance from the other row and plant spacing in each row was $5 \mathrm{~cm}$. Each plot had 6rows. The number of plants in each plot was 42 plants per square meter. The seeds were planted at a depth of $5 \mathrm{~cm}$, and immediately after planting, irrigation operation was carried out. After germination, irrigation was conducted in throughout the season according to farm's need. Removing weeds from plots, conducted manually fourtimes during the growing season. In order to achieve simultaneous seed ripening at the end of the growing season, their irrigation process were cut off.

After a full ripening of seedlings, 5 seedlings were harvested randomly in each plot from the crown part and separately weighted. Traits studied in this experiment were: Fresh and dry weight, plant height, distance of the first branch from ground, number of umbels, number of compound leaves, leaf surface area and fruit weight. Analysis of variance for collected data and comparison of means using Duncan's multiple tests at probability level of $1 \%$ were performed using SPSS software version 24 and Microsoft Excel was used for drawing charts.

\section{Results and discussion}

According to the results of analysis of variance (Table 1), (Table 2) the effects of different pre-treatments were significant on all traits under field conditions. Results showed that weight of the plants which primed with IAA (1.31times) was significantly increased in compare with control seeds (Figure 1). In general, applying priming on seeds of Coriander showed a remarkable positive effect on the plant's fresh weight. It has been reported that after planting the pre-treated seeds of soybeans, soybean yields have increased, which is dependent on the cultivar, So that the results of seed priming of different varieties of cultivars may be different and even contradictory. ${ }^{9}$ Javadi et al., ${ }^{10}$ reported that folic acid pre-treatment in wheat showed a noticeable increase in traits of fresh and dry weight of wheat, which is in line with the results of current research.

Table I Analysis of variance for studied traits

\begin{tabular}{|c|c|c|c|c|c|c|c|c|c|}
\hline S.O.V & DF & $\begin{array}{l}\text { Total Weight } \\
(\mathrm{mg})\end{array}$ & $\begin{array}{l}\text { Height } \\
(\mathrm{mm})\end{array}$ & $\begin{array}{l}\text { Distance of First } \\
\text { Branch }(\mathrm{mm})\end{array}$ & Umbels & $\begin{array}{l}\text { Compound } \\
\text { Leaves }\end{array}$ & $\begin{array}{l}\text { Dry } \\
\text { Weight } \\
\text { (mg) }\end{array}$ & $\begin{array}{l}\text { Leaf Aria } \\
(\mathrm{mm} 3)\end{array}$ & $\begin{array}{l}\text { Seeds } \\
\text { Weight } \\
(\mathrm{mg})\end{array}$ \\
\hline Treat & 9 & $4|62079| 2.5^{* *}$ & $56058.05 * *$ & $2728.05^{* *}$ & $310.3 * *$ & $70.958 * *$ & $31.929 * *$ & 3838080.6 ** & $881337.7^{* *}$ \\
\hline Rep & 3 & $58083202.5 \mathrm{n} . \mathrm{s}$ & II329.In.s & 749.In.s & $40.22 n . s$ & 12.158n.s & I.235n.s & 426427.09 n.s & 592936.6n.s \\
\hline Error & 27 & $I E+08$ & 4643.981 & 439.9 & 25.873 & 5.529 & 3.215 & 401091.6 & I23605.| \\
\hline CV (\%) & $\ldots$ & 26.36 & 10.05 & 27.32 & 14.58 & 19.38 & 21.22 & 18.53 & 19 \\
\hline
\end{tabular}

** : Significant at $\alpha=0.0$ I; n.s: Non-Significant. 
Table 2 Results of average treatment combination of traits under field conditions using Duncan

\begin{tabular}{|c|c|c|c|c|c|c|c|c|}
\hline \multirow{2}{*}{$\begin{array}{l}\text { Treat } \\
\text { Zinc }\end{array}$} & \multicolumn{2}{|c|}{ Total weight Height } & \multirow{2}{*}{$\begin{array}{l}\text { Distance of first } \\
\text { branch }\end{array}$} & \multirow{2}{*}{$\begin{array}{l}\text { Umbels } \\
32 \\
\end{array}$} & \multirow{2}{*}{$\begin{array}{l}\text { Compound } \\
\text { leaves } \\
13.25^{b}\end{array}$} & \multicolumn{2}{|c|}{ Dry weight Leaf aria } & \multirow{2}{*}{$\begin{array}{l}\text { Seeds } \\
\text { weight } \\
229.7^{\mathrm{bc}}\end{array}$} \\
\hline & $43540^{\mathrm{ac}}$ & $760^{\text {ce }}$ & & & & $13450^{d}$ & $3927.2^{\mathrm{bc}}$ & \\
\hline $\mathrm{H} 2 \mathrm{O}$ & $35292.5^{\mathrm{ac}}$ & $617.5^{\mathrm{ac}}$ & $80^{\text {be }}$ & $35.5^{b}$ & $10.5^{a}$ & $7240^{\mathrm{ab}}$ & $3935.5^{b c}$ & $1635^{\mathrm{ab}}$ \\
\hline Check & $24515^{a}$ & $605^{a b}$ & $50^{\mathrm{ab}}$ & $36.25^{b}$ & $10.25^{a}$ & $11275^{c d}$ & $3042.75^{b}$ & $1615^{\mathrm{ab}}$ \\
\hline Humic & $23282.5^{a}$ & $855^{e}$ & $110^{e}$ & $38.25^{b}$ & $18^{b}$ & $6152^{\mathrm{ab}}$ & $3509.5^{\mathrm{b}}$ & $2430^{c}$ \\
\hline Folic & $49530^{\mathrm{bc}}$ & $825^{e}$ & $107.5^{\text {de }}$ & $38^{b}$ & $8.25^{\mathrm{a}}$ & $1 \mid 582^{\text {cd }}$ & $4922.2^{c}$ & $1455^{a}$ \\
\hline IAA & $56665^{c}$ & $765^{\text {de }}$ & $70^{\mathrm{ae}}$ & $39.5^{b}$ & $8.75^{\mathrm{a}}$ & $8950^{\mathrm{bc}}$ & $3717.7^{\mathrm{bc}}$ & $2697.5^{c}$ \\
\hline GA3 & $34400^{\mathrm{ab}}$ & $677.5^{\text {bd }}$ & $100^{\text {ce }}$ & $52.5^{c}$ & $2 I^{b}$ & $4600^{a}$ & $1214.5^{\mathrm{a}}$ & $1375^{a}$ \\
\hline Ascorbic & $37890^{\mathrm{ac}}$ & $527.5^{\mathrm{a}}$ & $95^{\text {be }}$ & $29.5^{b}$ & $12: 00^{\mathrm{a}}$ & $8075^{\mathrm{ac}}$ & $2894^{b}$ & $1450^{\mathrm{ac}}$ \\
\hline $\mathrm{K} 2 \mathrm{SO} 4$ & $38707.5^{\mathrm{ac}}$ & $522.5^{\mathrm{a}}$ & $60^{\mathrm{ac}}$ & $18.5^{\mathrm{a}}$ & $9.5^{\mathrm{a}}$ & $6400^{\mathrm{ab}}$ & $3026.5^{b}$ & $1960^{\mathrm{ac}}$ \\
\hline$P$ & $35715^{\mathrm{ac}}$ & $\begin{array}{l}622.5^{\mathrm{ad}} \\
\mathrm{ad}\end{array}$ & $32.5^{\mathrm{a}}$ & $28.75^{b}$ & $9.75^{a}$ & $6750^{\mathrm{ab}}$ & $3986.7^{c d}$ & $1580^{a b}$ \\
\hline
\end{tabular}

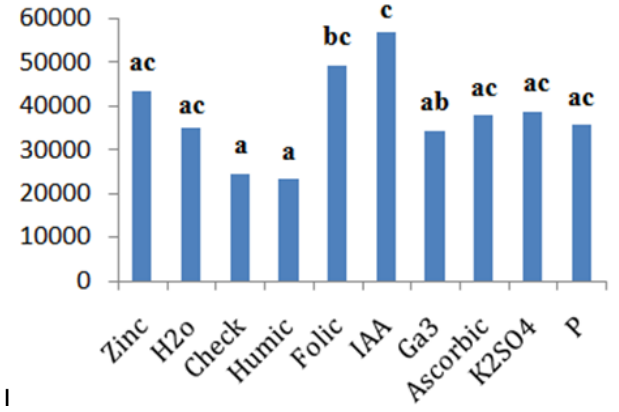

Figure I Effect of Pre-treatment on the weight.

Humic acid pre-treated plants (Figures 2) (Figure 3) showed an increase in two traits of; plant height (0.41times) and distance of the first branch from ground (1.2times) in comparison with control group. Ascorbic acid (0.12times) and Sulphate Potash $\left(\mathrm{K}_{2} \mathrm{SO}_{4}\right)$ (0.13times), reduced plant height. The pre-treats with Phosphorus (0.35times) reduced the distance of the first branch from ground. Seed priming can increase plant height by increasing distance of nodes..$^{11,12}$ Plants from primed Seeds, enhanced water and nutrients intake, in result they developed in height. ${ }^{13}$ Salimi et al. ${ }^{14}$ confirmed the positive effect of hydro priming of chickpea seeds on harvest index.

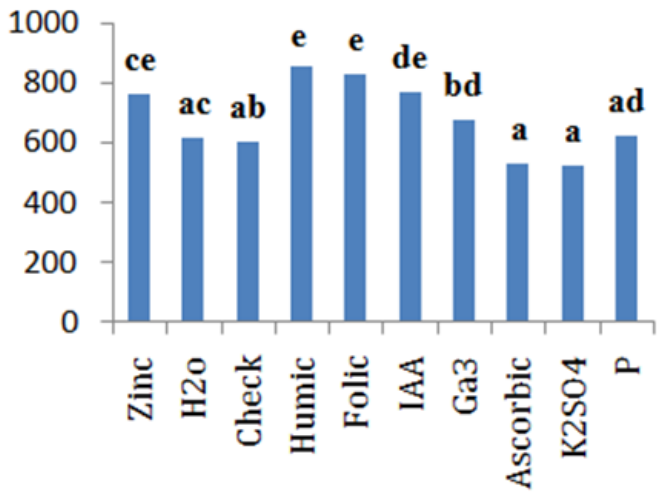

Figure 2 Effect of Pre-treatment on plant height.

In Sunflower, reported that priming seeds, improved dry matter, and increased harvest index, and also enhanced seed performance. ${ }^{15}$
$\mathrm{GA}_{3}$ pre-treated plants showed a significant increase in two traits of: number of umbels (0.44times) and compound leaves (1.04times), in comparison with control group (Figures 4) (Figure 5), while $\mathrm{K}_{2}$ $\mathrm{SO}_{4}$ (0.48times) reduced the number of umbels and also folic acid pre-treatment reduced the number of compound leaves (0.19times) in coriander. Applying of priming increases the seed performance by altering the mechanism of enzymes which are responsible in sucrose metabolism in the tissues of vegetative and reproductive structures. Total dry weight of the plants which primed with $\mathrm{Zn}$ (0.19times) showed a remarkable increase in comparing with control seeds (Figure 6), while $\mathrm{GA}_{3}$ pre-treated plants (0.59times) showed reduction in this trait. It seems that priming had a positive impact on total dry matter through effecting growth period and reducing germination period and in result total dry matter increased. Priming can increase the performance of wheat, corn, cotton in subtropical areas. This increase depends on plant type, variety, environmental conditions and type of treatment and also in obtained results priming effects was different according to the variety and pre-treatment type. ${ }^{16}$

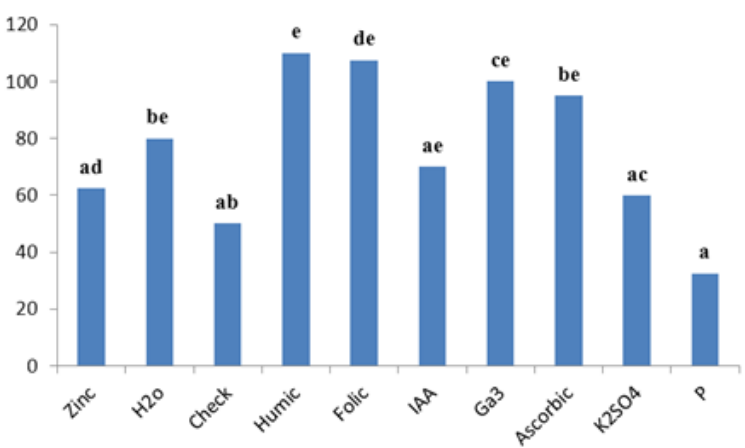

Figure 3 Effect of Pre-treatment on the distance of the first branch of the ground.

Enhanced activity of acid invertase in tissues of meristemic regions of plants, which produced from primed seeds of chickpea reported, that in result plant growth and biomass were increased.17 Hydro priming of bean seeds for 7 to 14 hours, increased characteristics such as percentage of seedling establishment, green surface, biomass and seed function. ${ }^{18}$ Leaf surface area of coriander which primed with folic acid (0.61 times) increased in compare with control croup, while $\mathrm{GA}_{3}$ 
pre-treated seeds of plant (0.60times) decreased in this trait (Figure 7). IAA pre-treat seeds showed a significant increase in seed weight (0.67times) in comparison with control group, while $\mathrm{GA}_{3}$ pre-treated plants reduced in weight of the seed (0.14times) (Figure 8).

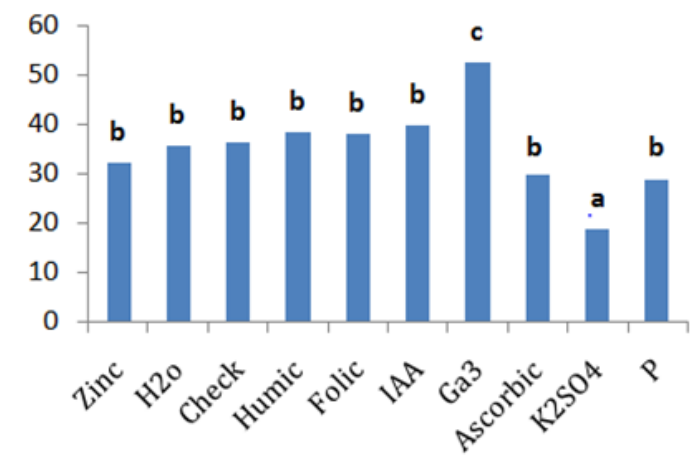

Figure 4 Effect of Pre-treatment on umbels.

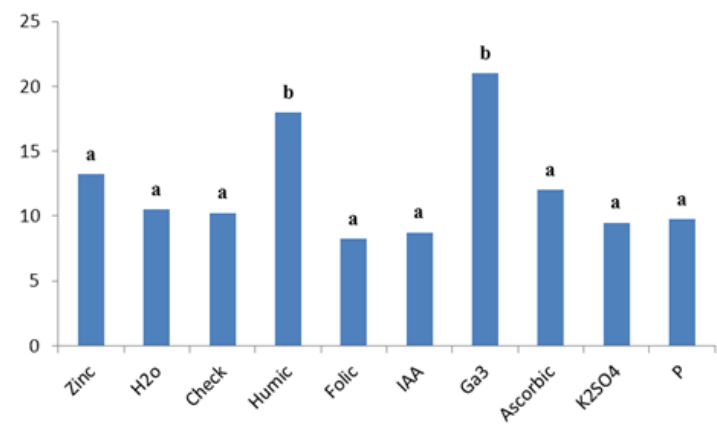

Figure 5 Effect of Pre-treatment on the number of Compound leaves.

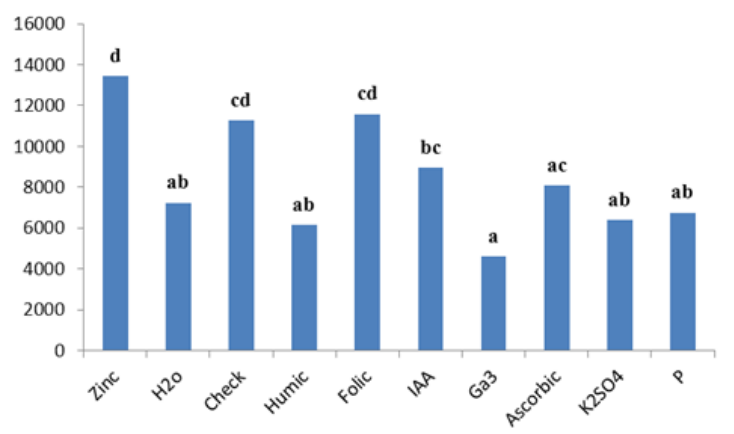

Figure 6 Pre-treatment effect on total dry Weight.

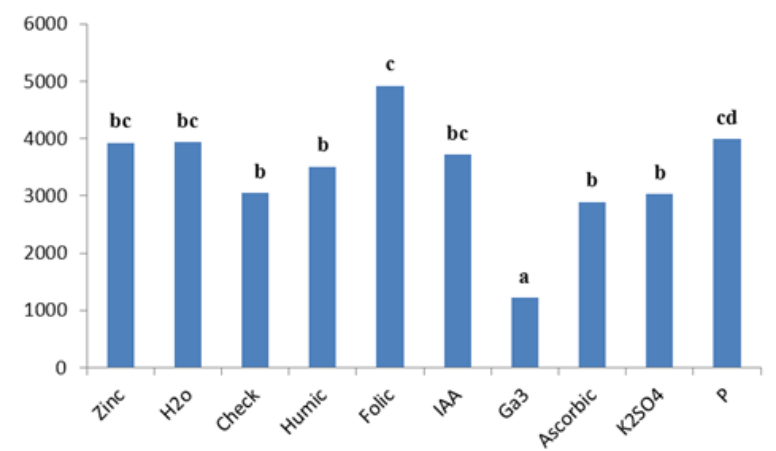

Figure 7 Effect of Pre-treatment on leaf area.
Increase in number of seeds depends on the availability of photosynthesis materials for plant and high concentrations of sucrose. ${ }^{19}$ One reported beneficial effects of pretreated seeds can be pointed to increased seed yield. ${ }^{20}$ Pre-treatment of seed, remarkably, increased seed yield-related traits in wheat. ${ }^{21}$ Osmopriming of canola seeds cause a significant increase in the number of pods that containing seed (klark et al). Applying Osmopriming, hardnig and matric priming in Brassica napus increased performance by improving factors such as the number of seeds per pod and seed weight. ${ }^{22}$ It seems that the seed priming cause a hormonal balance changes and improved seedling growth (Kur et al.).

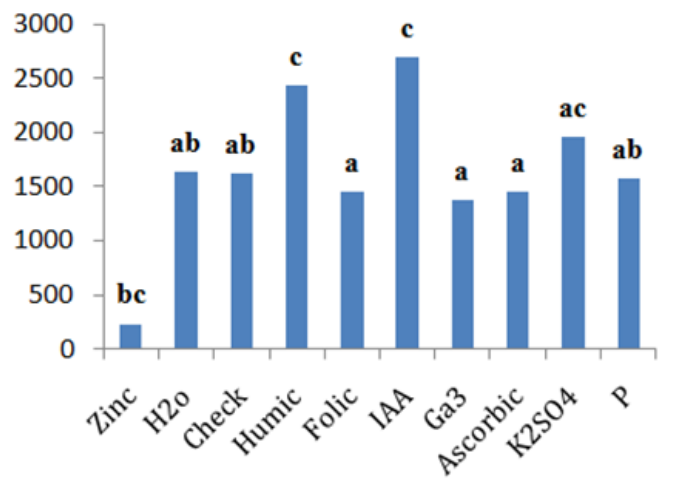

Figure 8 Effect of pre-treatment on seed weight.

\section{Conclusion}

All useful materials in plant, produced by their responsible genes, hence, Biotechnologists increased the power of expression and number of copies of these genes by priming, also this method increased the quantity of crops per hectare and the growth rate of plants by influencing the expressing of genes that are effective in growth and on the other hand priming has produced plants which are resistant to hard conditions. Applying priming had a positive and significant impact on the morphological and phonological traits of coriander.

But in some treatments that the priming of the seeds caused performance degradation, this decrease can be explained by the negative impact of concentration and types of material which had been tested. Accordingly, the type of material and the right concentration, in order to create a suitable osmotic condition and hormonal priming will have a significant impact on the results. So that the improper selection of material type and the concentration of the solution used in priming may not only improve the physiological characteristics of the treated seed and harvested plant, but the possibility of damages and degradation of biological characteristics of the treated seeds and subsequently the plants produced from these seeds would not be farfetched.

\section{Acknowledgments}

None.

\section{Conflict of interest}

The author declares no conflict of interest.

\section{References}

1. Subedi KD, Ma BL. Seed priming does not improve corn yield in a humid temperate environment. Agronomy Journal. 2005;97(1):211-218. 
2. Kaur SAK, Gupta N, Kaur. Effect of osmo-and hydropriming of chickpea seeds on seedling growth and carbohydrate metabolism under water deficit stress. Plant Growth Regulation. 2002;37(1):17-22.

3. Eisvand HR, Tavakkol, Afshari R, et al. Improvement of physiological quality of deteriorated tall wheat grass (Agropyronelongatum Host) seeds by hormonal priming for control and drought stress conditions. Iranian $J$ of Crop Sci. 2008;39:153-65.

4. Ghahraman A. Editor Iranian chromophytes. 1st ed. Tehran: Iran: University Press Center; 1994. 743 p.

5. Ullagaddi R, Bondada A. Medicinal benefits of coriander (Coriandrum Sativum L.). Spatula. 2011;1:51-58.

6. Blumenthal M, Goldberg A, Brinkmann J. Herbal medicine: expanded commission e monographs. Newton, MA: Integrative Medicine Communications; 2000. p. 75-77.

7. Dhanapakiam P, Joseph JM, Ramaswamy VK, et al. The cholesterol lowering property of coriander seeds (Coriandrum sativum): mechanism of action. J Environ Biol. 2008;29(1):53-56.

8. Eidi M, Eidi A, Saeidi A, et al. Effect of coriander seed (Coriandrum sativum L.) ethanol extract on insulin release from pancreatic beta cells in streptozotocin-induced diabetic rats. Phytother Res. 2009;23(3):404 406.

9. Saha R, Mandal AK, Basu RN. Physiology of seed invigoration treatments in soybean (Glycine max L.). Seed Sci Tech. 1990;18(2):269-276.

10. Javadi ASP, Esfandiari, Mousavi B. The effect of folic acid (vitamin B9) on germination of wheat under cadmium stress. Thirteenth Conference of Crop Sciencesn and the Third Conference of Seed Science and Technology. Seed and Plant Improvement Institute Karaj, Iran. 2013;24(26):288299.

11. Harris D, Raghuwnashi BS, Gangwar JS. Participatory evaluation by farmers of on-farm seed priming in wheat in India, Nepal and Pakistan. Exp Agric. 2001;37:403-415.

12. Musa AM, Harris D, Johansen C, et al. Short duration chickpea to replace fallow after aman rice: the role of on- farm seed priming in the high Bariand Tract of Bangladesh. Exp Agric. 2001;37(4):5509-5521.
13. Farooq M, Basra SMA, Warraich EA, et al. Optimization of hydro-priming techniques for rice seed invigoration. Seed Science and Technology. 2006;34(2):507-512.

14. Salimi H, Abbasdokht H, Asghari HR, et al. The effect of priming, Rhizobium and manure fertilizer on yield and yield components of chickpea (Cicer arietinum L). Testis of Master of science. Iran: Sanati Shahrod Univ; 1389. p. 1-120.

15. Hussain M, Malik MA, Farooq M, et al. Improving Drought tolerance by exogenous application of glycinebetaine and salicylic acid in sunflower J Agron Crop Sci. 2008;94(3):193-199.

16. Murungu FS, Chiduza P, Nyamugafata LJ, et al. Effects of on- farm seed priming on consecutive daily sowing occasions on the emergence and growth of maize in semi- arid Zimbabwe. Field crops Res. 2004;89(1):49-57.

17. Rashid A, Harris D, Hollington PA, et al. On-farm seed priming reduces yield losses of mung bean (Vigna radiata) associated with mung bean yellow mosaic virus in the North West Frontier Province of Pakistan. Crop Protection. 2004;23(11):1119-1124

18. Ghasemi Golezani K, Chadordooz Jeddi A, Nasrullahzade S, et al. Influence of hydro-priming duration on field performance of pinto bean (Phaseolus vulgaris L.) cultivars. African J Agri Res. 2010;5(9):893-897.

19. Egli D, BWP, Bruening. Source-sink relationships, seed sucrose levels and seed growth rates in soyben. Ann Bot. 2001;88(1):235-242.

20. Kaur S, Gupta A K, Kaur N. Seed priming increases crop yield possibly by modulating enzymes of sucrose metabolism in chickpea. $J$ of Agro Crop Sci. 2005;191(2):81-87.

21. Paul SR, Choudhary AK. Effect of seed priming with potassium salts on growth and yield of wheat under rainfed condition. Ann Agric Res. $1991 ; 12: 415-418$.

22. Afzal I, Aslam N, Mabood F, et al. Enhancement of canola seed by different priming techniques. Caderno de Pesquisa Ser Bio Santa Cruz do Sul. 2004;16:19-34. 